\title{
Augmented Reality and Virtual Reality- Based Technology in Cultural Tourism
}

Daniela Garbin Praničević

The University of Split, Faculty of Economics, Business and Tourism, Croatia

\begin{abstract}
The paper intends to scrutinize the effects of augmented (AR) reality and virtual reality (VR) technology implementation in cultural tourism. Therefore, the paper explored and presented the following: (i) $A R$, and $V R$ (AR/VR) based technology concept in general, (ii) AR/VR technologies application in cultural tourism with an emphasis on their potential to protect cultural heritage; (iii) the overview of AR/VR presence in cultural tourism in the 27 European Union countries (EU-27). In the discussion part, besides empirical results based on the EU-27 desk research, AR/VR technologies in cultural tourism are additionally reconsidered from the aspect of climate change. In conclusion, what is encouraged is the application of AR/VR in cultural tourism due to the benefits $A R$ and VR bring in terms of (i) delivering quite substantial content to their visitors any time from any place, (ii) reducing the negative impact of tourism on cultural heritage and (iii) developing related strategies based on more sustainable principles and concepts.
\end{abstract}

Keywords: AR and VR based technology, cultural tourism, sustainable principles, practice issues

JEL classification: 031, 033, Z19, Z32

Paper type: Research article

Received: Aug 09, 2021

Accepted: Aug 09, 2021

DOI: 10.54820/MHNY8236 


\section{Introduction}

Tourism has specific forms (so-called selective forms of tourism) that are oriented towards smaller segments of demand. One of the most prominent selective tourism forms is cultural tourism, which refers to the movements (visits) caused by cultural attractions beyond people's usual place of residence, intending to gather new information and experiences to meet their cultural needs (Smith, 2016). Although, over time cultural tourism significantly has been contributed to destination image upgrade (Govers et al., 2007), currently among few main challenges to cope on wider destination level become "how heritage and tourism goals integrate with marketing and management framework to produce sustainable cultural tourism" (du Cros et al., 2020). Referring to that, one of the most appropriate integrators seems just information and communication technology (ICT) which already contributed and improved numerous business performances worldwide, including cultural tourism (Tscheu et al., 2016; Jung et al., 2016, Tussyadiah et al., 2018). So many ICT solutions are used in an innovative way (i) to promote and sell cultural tourism products, (ii) to facilitate stakeholder participation for sustainable cultural tourism development (Chiabail et al., 2013), and (iii) assure better decisions on impacts on the economic, natural and socio-cultural environments with realistic scenarios available to engage all stakeholders including tourists, planners, and the local community" (Ali et al., 2014). Moreover within the complex process of establishing destination appeal (Mandic et al., 2019) ICT strengthen the subprocess of "material and socio-cultural revitalization of maturing destinations" (Marques et al., 2017).

With time, in addition to the websites of tourist boards, social networks, or mobile guides, the promotion of cultural tourism has been increasingly contributed by AR/VR technologies as innovative tools for storytelling and experiencing the story as real (Guerra et al., 2015; Yung et al., 2019). Through virtual and augmented reality, the user gets vivid destinations inside view and the feeling as to be "within" the destination itself, which consequently may increase the wider interest for cultural tourism (Guttentag, 2010). Moreover, AR/VR applications designed to support cultural tourism, actually change the tourism perspective regarding approaching, not only attractive products and services but the complete destination history, its present and past moments, to the visitors worldwide (Go et al., 2002; Jung et al., 2016; Tussyadiah et al., 2018).

In this context, there are still numerous cultural applications customized to precisely in 3D form inform tourists about cultural events, cultural institutions, and heritage, but also serve as a virtual tour guide (Lee et al., 2013) and "full or partial substitute for destinations that have exceeded their carrying capacity" (Ali et al., 2014). Detailed AR/VR specifies as well as its benefits to cultural tourism stakeholders supplemented with the empirical findings are enclosed in paragraphs below.

\section{Literature reviews}

\section{Technologies used for VR and $A R$}

Virtual meaning implies "not physically exist in the real world". VR technology is replacing the real world with the digital. It is completely immersive i.e. the user is isolated from the real world and is completely immersed in the virtual world (e.g. Google Cardboard-Google VR). Virtual reality (VR) is an apparent environment simulated with the support of special computer programs, providing users the illusion of being, moving, and perceiving (Tussyadiah et al., 2018). This three-dimensional multimedia environment is realized by visualizing the real or imagined environment presented on a computer screen or special stereoscopic devices (the most common 
device are glasses/goggles or a helmet with two built-in liquid crystal displays that enable insight in the virtual world only). The experience is complemented by sounds (with the support of headphones or speakers), vibrations, and the possibilities of arousing tactile and olfactory sensations. Applications of virtual reality are designed to support many areas like entertainment (e.g. video games), tourism (virtual tours), etc. education (e.g. trainings), business (e.g. virtual meetings), etc.

On the other side, "extended" means imply trios of the user, technology, and the real world, or in detail, a combination of real and virtual worlds, real-time interaction, and accurate 3D registration of virtual and real objects (Nayyar et al., 2018). As such, it allows the user to see elements that do not exist in real life through the application through the screen of a device, usually a mobile phone. These elements expand reality when viewed through a screen. The AR application allows viewing without the possibility of any interaction with the observed elements. Augmented reality adds elements of the virtual environment to the real world in a way that seems as they belong to the real world (Barnes, 2011), and serves as a technology for delivering attractive multimedia content tailored to different guest/visitors profiles.

Since AR technology connects the digital and the real world, it is a partially immersive option i.e. the user stays in touch with the real world, and at the same time interacts with virtual objects created within the real world (e.g. Snapchat filters, Pokemon Go...).

Given the complexity of the concept of virtual and augmented reality, there are different classifications of virtual/augmented reality systems according to different specifications and purposes (Edwards-Stewart et al., 2016; Flavian et al., 2019). The most commonly used one is by immersion level which refers to the credibility of physical inputs (e.g. light patterns and sound waves) and the way they are transmitted by different sensory modalities (sight, hearing, and touch) to create the illusion of reality (Mandal, 2013).

\section{$A R$ and $V R$ technologies in cultural tourism and related benefits}

From the technical perspective, AR/VR "add a layer of guidance, content, and entertainment" to preferred physical points of interest making them more informative and interactive for visitors. In the cultural tourism context, maps, wall maps, historical and other multilingual guides and serve as a kind of tourist information tool. One of up to date and growing use of AR relates to beacon technology that operates via Bluetooth in destinations (Shahriar, 2018), namely cultural institutions for sending push notifications or enabling certain functions when visitors enter a particular place.

The systematic review of numerous related studies (Yung et al., 2019) indicates that AR/VR technologies become an innovative and entertaining tool that, inter alia, enable visitors (i) immersion in important historical moments (iii) attractive education about the destination but also (iii) innovative option of how to experience the tourism product offerings. Following, but no less important AR/VR contributions in cultural tourism account: (i) initiating the positive word of mouth, (ii) rising visitor attendance and cultural heritage awareness, and (iii) providing direct feedback on the exhibition/museum/gallery impact and reach.

Therefore, not surprising that a highly respective number of destinations and the travel industry in general (Shah, 2019, Marr, 2021) are already using rich media on their websites to seek to reduce the intangibility aspect of the tourism product. The same trend is growing and is also perceived as growing (Transparency Market Research, 2021). 
Consequently, it is to be expected that as many countries in the EU as possible, as well as others in the world, have been recognized the importance of AR and VR for the development of their cultural tourism, and accordingly start to implement them.

\section{Methodology}

To verify the above-stated expectations, the author use desk research and secondary data accessed online to find out the presence of AR/VR solution in cultural tourism. The research domain covers 27 EU countries (EU-27) only.

Upon web research several related applications were detected per each country, however, only one application per observed EU country is chosen and presented in Table 1 (bellow). The choice "per country" is arisen from discussion in the classroom as highly ranked by tourism students - attendees the of $3^{\text {rd-year }}$ undergraduate study program at University of Split Faculty of Economics, Business and Tourism in the academic year 2020/2021.

\section{Results}

For each country from the sample, the desktop research resulted in at least one cultural tourism AR/VR application. Table 1 is, as methodologically explained above, presented one per country:

Table 1

AR / VR application in EU-27 countries

\begin{tabular}{|c|c|c|}
\hline Country & AR/VR app & App short description \& web access \\
\hline Austria & Vars AR \& VR & $\begin{array}{l}\text { virtual walks around the Austria cities } \\
\text { https://www.vars.at/augmented-reality-tour/ }\end{array}$ \\
\hline Belgium & $\begin{array}{l}\text { Historium VR } \\
\text { Brugge }\end{array}$ & $\begin{array}{l}\text { interactive tour of the medieval city of Bruges in virtual reality by } \\
\text { the support of Oculus - a designed display of virtual reality } \\
\text { https://www.historium.be/en/discover-historium/vr }\end{array}$ \\
\hline Bulgaria & $\begin{array}{l}\text { VR City Sofia } \\
\text { Independen } \\
\text { t Film Festival }\end{array}$ & $\begin{array}{l}\text { "So Independent" - festival of experimental short and AR and VR } \\
\text { films with a focus on art and innovation } \\
\text { https://www.vrcity.bg/en/ }\end{array}$ \\
\hline Croatia & $\begin{array}{l}\text { Barone } \\
\text { Fortress }\end{array}$ & $\begin{array}{l}\text { virtual tour through historic fortress with the buildings, graphic } \\
\text { markings and additional information about the marked building } \\
\text { enhanced with the animated narrator } \\
\text { https://www.tvrdjava-kulture.hr/hr/tvrdava-barone/prosirena- } \\
\text { stvarnost/ }\end{array}$ \\
\hline $\begin{array}{l}\text { Czech } \\
\text { Republic }\end{array}$ & $\begin{array}{l}\text { Virtual } \\
\text { Czech } \\
\text { Sights }\end{array}$ & $\begin{array}{l}\text { virtual tour through attractive destination in the Czech Republic } \\
\text { https://www.visitczechrepublic.com/en-US/News/2020/04/n- } \\
\text { virtual-czech-sights }\end{array}$ \\
\hline Cyprus & $\begin{array}{l}\text { TopGuide } \\
\text { Cyprus }\end{array}$ & $\begin{array}{l}\text { the application interface is similar to Google Maps, it locates the } \\
\text { device geolocation positions } \\
\text { http://myguide-ar.com/\#ar }\end{array}$ \\
\hline Denmark & Khora & $\begin{array}{l}\text { AR/VR support to various tours and insights into the historical } \\
\text { appearance of the abbey in Esrum, visit to the city of Holstebro, } \\
\text { virtual tours of Copenhagen National Museum of Denmark, } \\
\text { Christiansborg Palace, etc. } \\
\text { https://khora.com/museums-tourism/ }\end{array}$ \\
\hline Estonia & $\begin{array}{l}\text { Historical } \\
\text { Tartu }\end{array}$ & $\begin{array}{l}\text { virtual tour based on the history of Tartu, cultural and social } \\
\text { sights, e.g. Kivisild Bridge, Raatuse Street with Hotel Bellevue, } \\
\text { Illusioon - the first cinema in Estonia, etc. } \\
\text { https://www.visitestonia.com/en/virtual-reality-tour-vr-tartu-1913 }\end{array}$ \\
\hline
\end{tabular}




\begin{tabular}{|c|c|c|}
\hline Finland & $\begin{array}{l}\text { Virtual } \\
\text { Helsinki }\end{array}$ & $\begin{array}{l}\text { virtual city (tour) experience that allows visitors to "wander" with } \\
\text { the digital twin of Helsinki using 3D modelling } \\
\text { https://zoan.fi/work/virtual-helsinki/ }\end{array}$ \\
\hline France & $\begin{array}{l}\text { Complete } \\
\text { France }\end{array}$ & $\begin{array}{l}\text { AR/VR exploring France: } \\
\text { Château de Versailles, fragrant lavender fields of Provence, } \\
\text { Mont Blanc, Chauvet Cave, Montmartre, gardens of Villa } \\
\text { Ephrussi de Rothschild } \\
\text { https://www.completefrance.com/travel/holiday-ideas/9- } \\
\text { virtual-tours-of-france-1-6590936 }\end{array}$ \\
\hline Germany & $\begin{array}{l}\text { Museum } \\
\text { Städel, } \\
\text { Frankfurt }\end{array}$ & $\begin{array}{l}\text { virtual tour through reconstructed museum rooms from the 19th } \\
\text { century } \\
\text { https://www.staedelmuseum.de/en/offerings/time-machine }\end{array}$ \\
\hline Greece & Kotinos AR & $\begin{array}{l}\text { audio tour of the place and interactive quizzes about the } \\
\text { Olympics and life in ancient Olympia } \\
\text { https://www.youtube.com/watch? } v=\text { CKXT5yeCr4 }\end{array}$ \\
\hline Hungary & $\begin{array}{l}\text { Hungarian } \\
\text { National } \\
\text { Museum }\end{array}$ & $\begin{array}{l}\text { virtual tour through the Google Arts \& Culture platform. The } \\
\text { permanent collection of the National Museum contains more } \\
\text { than a million archaeological objects from the Hungarian } \\
\text { cultural heritage. } \\
\text { https://mnm.hu/en }\end{array}$ \\
\hline Ireland & $\begin{array}{l}\text { EPIC } \\
\text { Museum } \\
\text { The Irish } \\
\text { emigration } \\
\text { museum }\end{array}$ & $\begin{array}{l}\text { virtual tour of the museum with educational videos and audio } \\
\text { descriptions of galleries and historical paintings. } \\
\text { https://dublin.epicchq.com/virtual-tour-epic-the-irish- } \\
\text { emigration-museum?_ga=2.24790073.228964947.1608207040- } \\
629808867.1608207040\end{array}$ \\
\hline Italy & $\begin{array}{l}\text { Vatican } \\
\text { Museums }\end{array}$ & $\begin{array}{l}\text { virtual tours of the Vatican Museums. } \\
\text { http://www.museivaticani.va/content/museivaticani/it/collezion } \\
\text { i/musei/tour-virtuali-elenco.1.html }\end{array}$ \\
\hline Latvia & Latvia inside & $\begin{array}{l}\text { VR platform for the promotion of tourism and cities of Latvia } \\
\text { https://latviainside.com/vr/ }\end{array}$ \\
\hline Lithuania & $\begin{array}{l}\text { Gluk } \\
\text { media }\end{array}$ & $\begin{array}{l}\text { the digital story of the palace of Lithuanian dukes from the 13th } \\
\text { to the } 15 \text { th century, restored on a virtual reality tour. } \\
\text { http://glukmedia.com/ }\end{array}$ \\
\hline Luxemburg & $\begin{array}{l}\text { VR } \\
\text { Timetravel }\end{array}$ & $\begin{array}{l}\text { the part of "Smart City" concept of the Luxembourg city } \\
\text { including } 7 \text { locations such as Place Guillaume II or Place d" } \\
\text { Armes; users can access old photographs, historical films or 3D } \\
\text { maps. } \\
\text { https://www.youtube.com/watch?reload=9\&v=WTIUNFTUSBY }\end{array}$ \\
\hline Malta & $\begin{array}{l}\text { St.Paul's } \\
\text { Catacombs, } \\
\text { Il-Rabat }\end{array}$ & $\begin{array}{l}\text { a catacomb virtualization application developed in } 2107 \text { at the } \\
\text { Hamrun Institute } \\
\text { https://www.youtube.com/watch? } v=N v B w L O j h a 04\end{array}$ \\
\hline Netherlands & $\begin{array}{l}\text { Amsterdam } \\
\text { Area virtual } \\
\text { reality tour }\end{array}$ & $\begin{array}{l}4 \text { videos supported by virtual reality enable the Amsterdam } \\
\text { sightseeing } \\
\text { https://www.iamsterdam.com/en/blog/places/take-a-virtual- } \\
\text { reality-tour-of-the-amsterdam-area }\end{array}$ \\
\hline Poland & Visit Poland & $\begin{array}{l}\text { virtual insight into the offer Poland as a tourist destination } \\
\text { https://visitpoland.online/en/ }\end{array}$ \\
\hline Portugal & $\begin{array}{l}\text { Photojpl.co } \\
\mathrm{m}\end{array}$ & $\begin{array}{l}\text { virtual tour of Pena National Palace, and other locations in } \\
\text { Portugal (Moors Castle, Belem Tower, Alcobaca Monastery, ...) } \\
\text { http://photojpl.com/cities/portugal-cities/ }\end{array}$ \\
\hline
\end{tabular}




\begin{tabular}{|c|c|c|}
\hline Romania & $\begin{array}{l}\text { Projekt } \\
\text { Tango i } \\
\text { ARCore } \\
\text { Software } \\
\text { Developmen } \\
\text { † Kit }\end{array}$ & $\begin{array}{l}\text { AR/VR view a number of locations such as the Church of the } \\
\text { Biserica Neagra and the Hotel Acasa la Dracula } \\
\text { https://vr4holiday.com/estate_property/360-vr-palace-of-the- } \\
\text { parliament-casa-poporului-bucharest-romania-5k-hd-4k-virtual- } \\
\text { reality-travel/ }\end{array}$ \\
\hline Slovakia & $\begin{array}{l}\text { Virtual Tour } \\
\text { IN Orava } \\
\text { Castle }\end{array}$ & $\begin{array}{l}\text { virtual tour in Orava Castle based on the film perspective } \\
\text { "Nosferatu" } \\
\text { https://www.youtube.com/watch?v=N4vzjD } 400 E Y\end{array}$ \\
\hline Slovenia & $\begin{array}{l}\text { travel } \\
\text { Slovenia }\end{array}$ & $\begin{array}{l}\text { innovative AR project focused on preserving cultural heritage } \\
\text { and strengthening local tourism in Slovenia } \\
\text { http://www.travel-ar.si/en/ }\end{array}$ \\
\hline Spain & $\begin{array}{l}\text { Spain } \\
\text { Headout } \\
\text { from home }\end{array}$ & $\begin{array}{l}\text { virtual visit to the cities of Barcelona, Madrid, Cordoba, Bilbao, } \\
\text { Granada and Seville. Locations in cities are displayed using } \\
\text { images, audio and video } \\
\text { https://www.headout.com/blog/virtual-travel-to-spain/ }\end{array}$ \\
\hline Sweden & Visit Sweden & $\begin{array}{l}\text { Swedish nature in Virtual reality } \\
\text { https://visitsweden.com/what-to-do/nature- } \\
\text { outdoors/nature/sweden-vr-films/ }\end{array}$ \\
\hline
\end{tabular}

Note: Each web sites in Table 1 was accessed and approved "as active" on June 15th 2021 Source: Author's research

\section{Discussion}

According to research findings the observed countries recognized the potential of AR/VR technologies, and successfully uses them. It means that EU-27 visitors due to AR / VR offered apps enjoy opportunities to view the eminent EU-27 historical events and get cultural experiences of related destinations. Moreover, along with attractive sightseeing, the app based on AR technologies promotes more of its interesting cultural details as long as the visitors interact with their apps. Those visitors are invited to simply use their smartphone or tablet to experience an augmented version of their view in a museum or any other cultural heritage location.

The enclosed results indicate that cultural tourism in EU-27 countries enjoys, besides previously mentioned AR/VR technology benefits, and some more. Particularly, due to their potential, AR/VR contributes to their cultural tourism by preventing the decay of the sites/attractions by reducing tourist numbers and related traffic impacts. This item seems to be quite important for those in EU-27 concerned about the long-term. Namely, the respective management of sustainable cultural tourism is defined by principles of tourism but also by the principles of cultural heritage. From that point of view, just AR/VR based cultural tourism products are those developed within a preferred framework of sustainable development. By enabling presenting intangible cultural heritage without compromising its values, AR/VR solutions systematically enhance the sustainable use of cultural assets.

Furthermore, in the COVID-19 pandemic era, VR almost replaced physical travel what in (Guttentag, 2010) was already predicted. In addition, as climate change raises more concerns, the forthcoming period may result in air travel reduction with the purpose to protect and preserve the environment. These and similar travel limitations are consequently assumed as a trigger for more people to use virtual tourism offerings to experience cultural attractions they are not able to visit in a specific period. 


\section{Conclusion}

Following these paper findings, applying AR/VR technologies produce added value for the cultural tourism domain. With the support of technology, visitors can "digitally meet" cultural heritage in its original appearance.

This technology offers many benefits and reflects the value to visitors to learn about history while having fun. Well-known world destinations such as EU countries have already integrated modern technologies into their offer, and this trend will continue to spread and those other destinations will embrace modern technologies as an additional product. With the benefits of VR/AR technologies, the implementations of VR/AR technologies continue to attract visitors and investors (Transparency market research (2021).

Although, the practice alert (Dilek, 2018, Chen, 2020) some shortcomings and threats referring to AR/VR app in cultural tourism, such as (i) limitations in technology due to underdeveloped hardware in particular cases, (ii) lack of cultural interaction, (iii) negative effects on employment in tourism and related sectors or (iv) financial problems appearing when buying/replacing/upgrading virtual and augmented reality equipment, the AR/VR opportunities (Dilek, 2018) are prevailed for now.

Having in mind that the AR/VR based technology is used as well in other tourism segments such as (Tussyadiah et al., 2018): accommodation, restaurants, experience creation, transportation, and translation VR postcards, the EU-27 (but also other countries worldwide) the related AR/VR added value are presumptive too. However, as an extension of this research, the future ones will be focused on the following: (i) detailed SWOT analysis of the AR/VR in cultural tourism in general, and (ii) appliance of AR/VR technologies in the cultural tourism of other both, European and transcontinental, countries. Such comparison results, but also individual ones, are perceived as useful input for developing cultural tourism strategies worldwide.

\section{References}

1. Ali, A., Frew,A. J. (2014), "Technology innovation and applications in sustainable destination development", Information Technology \& Tourism, Vol. 14 No. 4, pp. 265-290.

2. Barnes, S. J. (2011), "Understanding use continuance in virtual worlds: empirical test of a research model", Information and Management, Vol. 48 No. 8, pp. 313-319.

3. Chen, D. (2020), "Virtual Reality Vacation Offers New Kind of Entertainment, Tourism Review News", available at: https://www.tourism-review.com/travel-tourism-magazinevirtual-reality-vacation-pros-and-cons-article2748 (23June 2021)

4. Chiabai, A., Paskaleva, K., Lombardi, P. (2013), "E-Participation model for sustainable cultural tourism management: A bottom-up approach", International Journal of Tourism Research, Vol.15 No. 1, pp. 35-51.

5. Dilek, S. (2018), "Virtual reality or just reality? A SWOT analysis of the tourism industry", Journal of Tourismology, Vol.4 No. 1, pp. 67-74.

6. du Cros, H., McKercher, B. (2020), Cultural Tourism, Routledge.

7. Edwards-Stewart A., Hoyt T., Reger G. (2016), "Classifying different types of augmented reality technology", Annual review of cybertherapy and telemedicine, Vol. 14, pp. 199202.

8. Flavián, C., Ibáñez-Sánchez, S., Orús, C. (2019), "The impact of virtual, augmented and mixed reality technologies on the customer experience", Journal of business research, Vol. 100, pp. 547-560.

9. Go, F. M, Lee, R. M., Russo, A. P. (2003), "e-Heritage in the Globalizing Society: Enabling Cross-Cultural Engagement through ICT", Journal of Information Technology \& Tourism, Vol. 6 No. 1, pp. 55-68.

10.Govers, R., Go, F. M., Kumar, K. (2007), "Promoting tourism destination image" Journal of travel research, Vol. 46 No. 1, pp.15-23. 
11.Guerra, J. P., Pinto, M. M., Beato, C. (2015), "Virtual reality-shows a new vision for tourism and heritage", European Scientific Journal, Vol. 11 No. 9, pp. 49-54.

12.Guttentag, D. A. (2010), "Virtual reality: Applications and implications for tourism", Tourism Management, Vol. 31 No. 5, pp. 637-651.

13.Jung T., Dieck M. C. T., Lee H., Chung N. (2016), "Effects of Virtual Reality and Augmented Reality on Visitor Experiences in Museum", in: Inversini, A., Schegg, R. (Eds), Information and Communication Technologies in Tourism, Springer, Cham, pp. 621-635.

14.Lee, K., Lee, H. R., Ham, S. (2013), "The effects of presence induced by smartphone applications on tourism: Application to cultural heritage attractions", in: Information and communication technologies in tourism, Springer, Cham, pp. 59-72.

15.Mandal, S. (2013), "Brief Introduction of Virtual Reality \& its Challenges", International Journal of Scientific \& Engineering Research, Vol. 4 No. 4, pp. 304-309.

16.Mandić, A., Garbin Praničević, D. (2019), "Progress on the role of ICTs in establishing destination appeal: Implications for smart tourism destination development", Journal of Hospitality and Tourism Technology, Vol. 10 No. 4, pp. 791-813.

17.Marques, L., Borba, C. (2017), "Co-creating the city: digital technology and creative tourism", Tourism Management Perspectives, Vol. 24, pp. 86-93.

18.Marr, B. (2021), "The Amazing Ways VR and AR Are Transforming the Travel Industry", available at: https://www.forbes.com/sites/bernardmarr/2021/04/12/the-amazing-ways-vrand-ar-are-transforming-the-travel-industry/? sh=19db171b36e0 (15 June 2021)

19.Nayyar, A., Mahapatra, B., Le, D., Suseendran, G. (2018), "Virtual Reality (VR) \& Augmented Reality (AR) technologies for tourism and hospitality industry", International journal of engineering \& technology, Vol. 7 No. 21, pp.156-160.

20.Shah, M. (2019), "How Augmented Reality (AR) is Changing the Travel \& Tourism Industry", available at: https://towardsdatascience.com/how-augmented-reality-ar-is-changingthe-travel-tourism-industry-239931f3120c (21 June 2021)

21.Shahriar, K. N. (2018), "Implementation of Beacon Technology in Tourism DestinationsAnalysis of case study on the influence of iBeacons and future implementation in Munich Ocotberfest", pp. 1-25.

22.Smith K. M. (2016), Issues in Cultural Tourism Studies, Routlege.

23. Transparency market research (2021), "AR/VR in Tourism Industry Market - Global Industry Analysis, Size, Share, Growth, Trends, and Forecast, 2021-2031", available at: https://www.transparencymarketresearch.com/arvr-in-tourism-industry-market.html (12 July 2021)

24.Tscheu, F., Buhalis, D. (2016), "Augmented Reality at Cultural Heritage sites", in: Inversini, A., Schegg, R., (Eds.), Information and Communication Technologies in Tourism 2016 ENTER, Springer, pp. 607-619.

25.Tussyadiah, I., Wang, D., Jung, T. H., Dieck M. C. T. (2018), "Virtual Reality, Presence, and Attitude Change: Empirical Evidence from Tourism", Tourism Management, Vol. 66, pp. $140-154$.

26.Yung, R., Khoo-Lattimore, C. (2019), "New realities: a systematic literature review on virtual reality and augmented reality in tourism research", Current Issues in Tourism, Vol. 22 No. 17, pp. 2056-2081.

\section{About the author}

Daniela Garbin Praničević, Ph.D., is an Associate Professor of business informatics at the Faculty of Economics, Business, and Tourism, University of Split. Her M.A. degree is received in Information Management at the Faculty of Economics, University of Zagreb, and the Ph.D. degree in Business Informatics at the Faculty of Economics, Business, and Tourism, University of Split. Her research interests are knowledge management, ICT project management, and ICT appliance in education and business, particularly in tourism and hospitality. She participated in a few research projects and published papers based on the project results. The author can be contacted at daniela@efst.hr 